\title{
Growth and yield response of bitter gourd to foliar applied urea under different irrigation levels
}

\author{
Abdul Samad ${ }^{1}$, Fazal Muhammad Bangulzai ${ }^{2 *}$, Zakia Bibi ${ }^{2}$, Abdul \\ Raziq $^{2}$, Syed Muhammad Ishaq ${ }^{2}$, Shabeer Ahmed ${ }^{2}$, Shah Faisal ${ }^{2}$, Lal \\ Bakhsh $^{3}$ and Abdul Qadir ${ }^{4}$ \\ 1. Sindh Agriculture University Tandojam, Sindh-Pakistan \\ 2. Agriculture Research Institute (A.R.I) Sariab Quetta, Balochistan-Pakistan \\ 3. Directorate of Agriculture Research, Usta Muhammad Balochistan-Pakistan \\ 4. Horticulture Research Institute BARDC (PARC) Khuzdar-Pakistan \\ *Corresponding author's email: fazalbangulzai786@gmail.com \\ Citation \\ Abdul Samad, Fazal Muhammad Bangulzai, Zakia Bibi, Abdul Raziq, Syed Muhammad Ishaq, Shabeer Ahmed, Shah \\ Faisal, Lal Bakhsh and Abdul Qadir. Growth and yield response of bitter gourd to foliar applied urea under different \\ irrigation levels. Pure and Applied Biology. Vol. 8, Issue 1, pp50-57. http://dx.doi.org/10.19045/bspab.2018.700163 \\ \begin{tabular}{llll}
\hline \hline Received: 07/08/2018 & Revised: 02/10/2018 & Accepted: 03/10/2018 & Online First: 06/10/2018 \\
\hline \hline
\end{tabular}
}

\section{Abstract}

In order to examine the growth and yield response of bitter gourd to foliar applied urea at different concentrations and irrigation at various frequencies, the experiment was conducted during 2016 using 3 replicated Randomized Complete Block Design at Sindh Agriculture University Tandojam. Irrigation was applied at weekly interval $\left(\mathrm{T}_{1}\right)$, Irrigation at 10 days interval $\left(\mathrm{T}_{2}\right), \mathrm{T}_{2}+$ foliar urea @ 1.5\% $\left(\mathrm{T}_{3}\right), \mathrm{T}_{2}+$ foliar urea @ 3\% $\left(\mathrm{T}_{4}\right)$, Irrigation at 15 days interval $\left(\mathrm{T}_{5}\right), \mathrm{T}_{5}+$ foliar urea @ 1.5\% $\left(\mathrm{T}_{6}\right), \mathrm{T}_{5}+$ foliar urea @ 3\% $\left(\mathrm{T}_{7}\right)$. The results revealed that Irrigation at 10 days interval + foliar urea at $3.0 \%$ conc.proved to be an optimum treatmentand resulted in $144.95 \mathrm{~cm}$ vine length, 19.96 $\mathrm{cm}$ fruit length, $17.45 \mathrm{~cm}$ diameter of fruit, $79.95 \mathrm{~g}$ average fruit weight, 8.95 number of fruits vine ${ }^{-}$ $1,739.00 \mathrm{~g}$ weight of fruits vine ${ }^{-1}$ and $9199.7 \mathrm{~kg} \mathrm{ha}^{-1}$ fruit yield. The irrigation at 10 days interval + foliar application of urea (1.5\%)ranked $2^{\text {nd }}$; irrigation at 15 days interval + foliar urea $(3.0 \%)$ ranked $3^{\text {rd }}$; irrigation at 15 days interval + foliar urea $(1.5 \%)$ ranked $4^{\text {th }}$; while weekly (control), 10 days, 15 days irrigation interval without foliar applied urea ranked $5^{\text {th }}, 6^{\text {th }}$ and $7^{\text {th }}$ respectively. The values for all the growth and productivity of bitter gourd were markedly increased with foliar application of urea, particularly at higher concentration. It was concluded that for acghieving desired yield performance of bittergourd the crop may be irrigted at 10 days interval + foliar application of urea at $3.0 \%$ conc.

Keyword: Bitter gourd; Irrigation; Urea conc.; Yield

Introduction

Bitter gourd, botanically named as Momordica charantia belongs to the Cucurbitaceae family in Momordica genus of climbing vines produce a tender, edible fruit pod [1]. The center of bitter gourd domestication likely lies in eastern Asia, possibly eastern India or southern China [2]. The bitter gourd is very useful for health by virtue of its disease preventing and health promoting phytochemical compounds. Bitter gourd is generally consumed cooked in the 
green or early yellowing stage. Bitter gourd is very popular throughout South Asia. It is often prepared with potatoes and served with yogurt on the side to offset the bitterness [3]. In Pakistan and Bangladesh, bitter gourd is often cooked with onions, red chili powder, turmeric powder, salt, coriander powder, and a pinch of cumin seeds [4]. A $100 \mathrm{~g}$ edible portion of bitter gourd contains $93.95 \mathrm{~g}$ moisture, 19 Kcal energy, 4.32 g carbohydrates, $1.95 \mathrm{~g}$ sugars, $2 \mathrm{~g}$ dietary fiber, $0.18 \mathrm{~g}$ fat, $0.84 \mathrm{~g}$ protein, $6 \mu \mathrm{g}$ Vitamin A, $68 \mu \mathrm{g}$ beta-carotene, $1323 \mu \mathrm{g}$ lutein zeaxanthin, $0.051 \mathrm{mg}$ thiamine, $0.053 \mathrm{mg}$ riboflavin, $0.28 \mathrm{mg}$ niacin, $0.193 \mathrm{mg}$ pantothenic acid, $0.041 \mathrm{mg}$ vitamin $\mathrm{B}_{6}, 51$ $\mathrm{mg}$ folate, $33 \mathrm{mg}$ vitamin $\mathrm{C}, 0.14 \mathrm{mg}$ vitamin $\mathrm{E}, 4.8 \mu \mathrm{g}$ vitamin $\mathrm{K}, 9 \mathrm{mg}$ calcium, $0.38 \mathrm{mg}$ iron, $16 \mathrm{mg}$ magnesium, $0.086 \mathrm{mg}$ manganese, $36 \mathrm{mg}$ phosphorus, $319 \mathrm{mg}$ potassium, $6 \mathrm{mg}$ sodium, $0.77 \mathrm{mg}$ zinc [5].

The availability of irrigation water is the fundamental requirement for crop production and the availability or judicious use of irrigation water Scarcity of water resources is a worldwide issue due to the increasing demand [6]. The pressure on water resources is expected to increase as the requirements for food production and industrial needs go up in parallel with rapidly growing population [7]. Water resources are limited worldwide and there is an urgent need to identify and adopt efficient irrigation management strategies since irrigation of agricultural lands accounts for over $85 \%$ of worldwide water usage $[8,9]$ indicate that crop water use efficiency can be increased either by improving the irrigation scheduling and the crops may be saved from water stress at its critical growth stages. At leaf level, the increase in transpiration efficiency may result both from an increase in photosynthetic rate and a decrease in stomatal conductance [10]. Irregular and inadequate water supply affects the growth, yield and fruit quality in vegetables; and irrigated vegetables produce good yields every year, but the response to irrigation may vary greatly from one year to the next depending upon the amount and distribution of rainfall during the growing season. A thorough soaking every four to five days on light, sandy soils and every seven to ten days on heavy soils is a good general guide for irrigating if no enough rains. Early watering in the day to cut down on evaporation losses and to give the foliage plenty of time to dry out is suggestible [11]. Foliar application of urea is low cost and gives rapid plant response. The foliar application of urea can not only optimize the nitrogen supply to the plant, but the plant also withstand under water stress and drought conditions [12] found that once foliar applied urea is absorbed by the leaves it converted to ammonia. Foliar applied urea is found to be highly effective on and if major portion of nutrients is taken up through the foliage, it would not contribute greatly to denitrification [13]. The studies indicated that nitrogen through soil or in foliar form improves plant growth and yield $[14,15]$ and foliar form of nitrogen application is more effective, particularly in water shortage and drought conditions [16]. However, soil application of nutrients is essential [17]. The conjunctive use of nutrients through soil and foliar method produce better impact on crop growth and fruit yield than using any single method of nutrient application [18]. The proposed experiment was carried out to examine the yield response of bitter gourd to different irrigation levels and foliar applied urea under field conditions.

\section{Materials and methods}

The experiment was laid out in three replicated Randomized Complete Block Design at the experimental field of the Orchard, Department of Horticulture, Sindh Agriculture University Tandojam having net plot size of $3.5 \mathrm{~m} \times 5.0 \mathrm{~m}\left(17.5 \mathrm{~m}^{2}\right)$. The crop was fertilized with different levels of foliar applied urea. Apart from the foliar applied 
urea, the crop was treated with recommended dose of NPK (100-75-50 kg ha ${ }^{-1}$ ). All P and $\mathrm{K}$ along with $1 / 2$ Nitrogen was applied at the time of sowing. The remaining Nitrogen was divided into two equal splits and was applied at flowering and fruiting stages, respectively. The irrigations was applied as per treatment plan and 1.5 to 3.0 gram urea was dissolved in 100 liter water to prepare solution for foliar application. The soil applied NPK fertilizers was applied at the recommended rates of 100$75-50 \mathrm{~kg} \mathrm{ha}^{-1}$ in the form of Urea, Single Super Phosphate and Sulphate of Potash, respectively. All the cultural practices were operated as per the recommendations in all the plots uniformly. The observations was recorded on the basis of five selected vines in each plot.

The analysis of variance was employed to examine the significance for each character for overall treatments, while the L.S.D. (Least Significant Differences) test was employed to compare the treatment means, following the statistical methods suggested [19].

\section{Results}

\section{Vine length $(\mathrm{cm})$}

Vine length of bitter gourd is an important growth trait and it influences the yield parameters. The results related to bitter gourd as affected by different irrigation frequencies are given in (Table1). There was a significant increase $(\mathrm{P}<0.05)$ in vine length for different irrigation frequencies. The maximum vine length $(144.95 \mathrm{~cm})$ was noted when bitter gourd was irrigated at 10 days interval + foliar application of urea at $3.0 \%$ conc., followed by vine length of 143.50, 142.00 and $139.50 \mathrm{~cm}$ in bitter gourd when crop was irrigated at 10 days interval + foliar application of urea at $1.5 \%$ conc., 15 days interval + foliar application of urea at $3.0 \%$ conc. and 15 days interval + foliar application of urea at $1.5 \%$ conc., respectively. The vine length (134.50 and $124.50 \mathrm{~cm})$ was noted when bitter gourd was irrigated at Control (irrigation at weekly interval) and Irrigation at 10 days interval. The lowest vine length $(120.50 \mathrm{~cm})$ was noted when bitter gorud irrigated at 15 days interval. It was observed that bitter gourd fruit produced highest vine length when irrigated at 10 days interval + foliar application of urea at $3.0 \%$ conc. The LSD test demostrated signifcant $(\mathrm{P}<0.05)$ in vine length between all irrigation levels.

\section{Fruit length (cm)}

Fruit length $(\mathrm{cm})$ in bitter gourd is an important growth trait and it influences the yield parameters. The results related to bitter gourd as affected by different irrigation frequencies are given in (Table1). There was significant increase $(\mathrm{P}<0.05)$ in fruit length for different irrigation frequencies. The maximum fruit length $(19.96 \mathrm{~cm})$ was noted when bitter gourd was irrigated at 10 days interval + foliar application of urea at 3.0\% conc., followed by fruit length of 17.98 , 17.10 and $16.04 \mathrm{~cm}$ in bitter gourd when irrigated at 10 days interval + foliar application of urea at $1.5 \%$ conc., 15 days interval + foliar application of urea at $1.5 \%$ conc. and irrigated at Control (irrigation at weekly interval), respectively. The minimum fruit length $(15.61$ and $12.67 \mathrm{~cm})$ was noted when bitter gourd was irrigated at 10 days interval and 15 days interval + foliar application of urea at $1.5 \%$ conc. The lowest fruit length $(11.96 \mathrm{~cm})$ was noted when bitter gorud was irrigated at 15 days interval. It was observed that bitter gourd produced highest fruit length when irrigated at 10 days interval + foliar application of urea at $3.0 \%$ conc. The LSD test demostrated signifcant $(\mathrm{P}<0.05)$ difference in fruit length between all irrigation levels.

\section{Diameter of fruit $(\mathbf{c m})$}

Diameter of fruit of bitter gourd is an important growth trait and it influences the yield parameters. The results related to bitter gourd as affected by different irrigation frequencies are given in (Table1). There was significant increase $(\mathrm{P}<0.05)$ in fruit diameter 
for different irrigation frequencies. The maximum diameter of fruit $(17.45 \mathrm{~cm})$ was noted when bitter gourd was irrigated at 10 days interval + foliar application of urea at $3.0 \%$ conc., followed by diameter of fruit of $16.63,16.27$ and $15.55 \mathrm{~cm}$ in bitter gourd when irrigated at 10 days interval + foliar application of urea at $1.5 \%$ conc., 15 days interval + foliar application of urea at $3.0 \%$ conc. and 15 days interval + foliar application of urea at $1.5 \%$ conc., respectively. The diameter of fruit $(15.27$ and $15.70 \mathrm{~cm})$ was noted when bitter gourd was irrigated at Control (irrigation at weekly interval) and irrigation at 10 days interval. The lowest diameter of fruit $(12.43 \mathrm{~cm})$ was noted when bitter gorud was irrigated at 15 days interval. It was observed that bitter gourd fruit produced highest diameter of fruit when irrigated at 10 days interval + foliar application of urea at $3.0 \%$ conc. The LSD test demostrated signifcant increase $(\mathrm{P}<0.05)$ in diameter for fruit between all irrigation levels.

Table 1. Effect of various combinations of irrigation frequencies and foliar application of urea in different conc. on Vine length $(\mathrm{cm})$, Fruits length $(\mathrm{cm})$, Diameter of fruit $(\mathrm{cm})$ and Average fruit weight (g) of bitter gourd

\begin{tabular}{|c|c|c|c|c|}
\hline Treatments & $\begin{array}{c}\text { Vine length } \\
\text { (cm) }\end{array}$ & $\begin{array}{c}\text { Fruit length } \\
(\mathbf{c m})\end{array}$ & $\begin{array}{c}\text { Diameter of } \\
\text { fruit }(\mathbf{c m})\end{array}$ & $\begin{array}{c}\text { Average fruit weight } \\
(\mathbf{g})\end{array}$ \\
\hline $\begin{array}{c}\text { Control (irrigation at } \\
\text { weekly interval) }\end{array}$ & $134.50 \mathrm{e}$ & $16.04 \mathrm{~d}$ & $15.27 \mathrm{c}$ & $67.86 \mathrm{e}$ \\
\hline $\begin{array}{c}\text { Irrigation at 10 days } \\
\text { interval }\end{array}$ & $124.50 \mathrm{f}$ & $15.61 \mathrm{e}$ & $15.70 \mathrm{bc}$ & $62.00 \mathrm{f}$ \\
\hline $\begin{array}{c}\text { Irrigation at 10 days } \\
\text { interval + foliar } \\
\text { application of urea at } \\
1.5 \% \text { conc. }\end{array}$ & $143.50 \mathrm{~b}$ & $17.98 \mathrm{~b}$ & $16.63 \mathrm{ab}$ & $77.47 \mathrm{~b}$ \\
\hline $\begin{array}{c}\text { Irrigation at 10 days } \\
\text { interval + foliar } \\
\text { application of urea at } \\
3.0 \% \text { conc. }\end{array}$ & $144.95 \mathrm{a}$ & $19.96 \mathrm{a}$ & $17.45 \mathrm{a}$ & $79.95 \mathrm{a}$ \\
\hline $\begin{array}{c}\text { Irrigation at 15 days } \\
\text { interval }\end{array}$ & $120.50 \mathrm{~g}$ & $11.96 \mathrm{~g}$ & $12.43 \mathrm{~d}$ & $52.00 \mathrm{~g}$ \\
\hline $\begin{array}{c}\text { Irrigation at 15 days } \\
\text { interval + foliar } \\
\text { application of urea at } \\
\text { 0.5\% conc. }\end{array}$ & $139.50 \mathrm{~d}$ & $17.10 \mathrm{c}$ & $15.55 \mathrm{bc}$ & $71.83 \mathrm{~d}$ \\
\hline $\begin{array}{c}\text { Irrigation at 15 days } \\
\text { interval + foliar } \\
\text { application of urea at } \\
3.0 \% \text { conc. }\end{array}$ & $142.00 \mathrm{c}$ & $12.67 \mathrm{f}$ & $16.27 \mathrm{abc}$ & $75.50 \mathrm{c}$ \\
\hline SE \pm & 0.4645 & 0.1036 & 0.5816 & 0.5087 \\
\hline LSD 0.05 & 1.0120 & 0.2216 & 1.2672 & 1.1083 \\
\hline CV (\%) & 0.42 & 2.06 & 4.56 & 0.90 \\
\hline
\end{tabular}

\section{Average fruit weight $(\mathrm{g})$}

Average fruit weight ( $\mathrm{g}$ ) of bitter gourd is an important growth trait and it influences the yield parameters. The results related to bitter gourd as affected by different irrigation frequencies are given in (Table1). There was significant increase $(\mathrm{P}<0.05)$ in average fruit weight for different irrigation frequencies. 
The maximum average fruit weight $(79.95 \mathrm{~g})$ was noted when bitter gourd was irrigated at 10 days interval + foliar application of urea at $3.0 \%$ conc., followed by average fruit weight of $77.47,75.50$ and $71.83 \mathrm{~g}$ in bitter gourd when irrigated at 10 days interval + foliar application of urea at $1.5 \%$ conc., 15 days interval + foliar application of urea at 3.0\% conc. and 15 days interval + foliar application of urea at $1.5 \%$ conc., respectively. The average fruit weight (67.86 and $62.00 \mathrm{~g}$ ) was noted when bitter gourd was irrigated at Control (irrigation at weekly interval) and Irrigation at 10 days interval. The lowest average fruit weight $(52.00 \mathrm{~g})$ was noted when bitter gorud was irrigated at 15 days interval. It was observed that bitter gourd fruit produced highest average fruit weight when irrigated at 10 days interval + foliar application of urea at $3.0 \%$ conc. The LSD test demostrated signifcant increase $(\mathrm{P}<0.05)$ in average fruit weight ( $\mathrm{g}$ ) among all irrigation levels.

\section{Number of fruits vine ${ }^{-1}$}

Number of fruits vine ${ }^{-1}$ in bitter gourd is an important growth trait and it influences the yield parameters. The results related to bitter gourd as affected by different irrigation frequencies are given in Table-2. There was significant increase $(\mathrm{P}<0.05)$ in number of fruits $v^{-1} e^{-1}$ for different irrigation frequencies. The maximum number of fruits vine $^{-1}(8.95)$ was noted when bitter gourd was irrigated at 10 days interval + foliar application of urea at $3.0 \%$ conc., followed by number of fruits vine ${ }^{-1}$ of $8.55,8.11$ and 7.85 in bitter gourd when irrigated at 10 days interval + foliar application of urea at $1.5 \%$ conc., 15 days interval + foliar application of urea at $3.0 \%$ conc. and 15 days interval + foliar application of urea at $1.5 \%$ conc., respectively. The number of fruits vine ${ }^{-1}$ (7.18 and 6.65) was noted when bitter gourd was irrigated at Control (irrigation at weekly interval) and Irrigation at 10 days interval. The lowest number of fruits vine ${ }^{-1}(5.15)$ was noted when bitter gorud was irrigated at 15 days interval. It was observed that bitter gourd fruit produced highest number of fruits vine $^{-1}$ when irrigated at 10 days interval + foliar application of urea at $3.0 \%$ conc. The LSD test demostrated signifcant increase $(\mathrm{P}<0.05)$ in number of fruits vine ${ }^{-1}$ amongall irrigation levels.

\section{Weight of fruits vine ${ }^{-1}(\mathrm{~g})$}

The weight of fruits vine ${ }^{-1}(\mathrm{~g})$ in bitter gourd is an important yield trait and it influences the yield parameters. The results related to bitter gourd as affected by different irrigation frequencies are given in (Table2). There was significant increase $(\mathrm{P}<0.05)$ in weight of fruits vine ${ }^{-1}$ for different irrigation frequencies. The maximum weight of fruits vine $^{-1}(739.00 \mathrm{~g})$ was noted when bitter gourd was irrigated at 10 days interval + foliar application of urea at $3.0 \%$ conc., followed by weight of fruits vine ${ }^{-1}$ of $710.00,678.33$ and $645.00 \mathrm{~g}$ in bitter gourd when irrigated at 10 days interval + foliar application of urea at $1.5 \%$ conc., 15 days interval + foliar application of urea at $3.0 \%$ conc. and 15 days interval + foliar application of urea at $1.5 \%$ conc., respectively. The weight of fruits vine ${ }^{1}$ (595.00 and $520.00 \mathrm{~g}$ ) was noted when bitter gourd was irrigated at Control (irrigation at weekly interval) and Irrigation at 10 days interval. The lowest weight of fruits vine ${ }^{-1}$ $(418.33 \mathrm{~g})$ was noted when bitter gorud irrigated at 15 days interval. It was observed that bitter gourd fruit produced highest weight of fruits vine ${ }^{-1}$ when irrigated at 10 days interval + foliar application of urea at $3.0 \%$ conc. The LSD test demostrated signifcant increase $(\mathrm{P}<0.05)$ in weight of fruits vine $^{-1}(\mathrm{~g})$ amongall irrigation levels.

Fruit yield (kg) ha-1

The fruit yield $\left(\mathrm{kg} \mathrm{ha}^{-1}\right)$ in bitter gourd is an important yield trait and it represents final yield. The results related to bitter gourd as affected by different irrigation frequencies are given in (Table2). There was significant increase $(\mathrm{P}<0.05)$ in fruit yield $\left(\mathrm{kg} \mathrm{ha}^{-1}\right)$ for 
different irrigation frequencies. The maximum fruit yield $\mathrm{ha}^{-1}(9199.7 \mathrm{~kg})$ was noted when bitter gourd was irrigated at 10 days interval + foliar application of urea at $3.0 \%$ conc., followed by fruit yield $\mathrm{ha}^{-1}$ of $9145.0,7940.0$ and $8320.0 \mathrm{~kg}$ in bitter gourd when irrigated at 10 days interval + foliar application of urea at $1.5 \%$ conc., 15 days interval + foliar application of urea at $3.0 \%$ conc. and 15 days interval + foliar application of urea at $1.5 \%$ conc., respectively. The fruit yield $\mathrm{ha}^{-1}(7876.7$ and $7305.0 \mathrm{~kg}$ ) was noted when bitter gourd was irrigated at Control (irrigation at weekly interval) and Irrigation at 10 days interval. The lowest fruit yield ha${ }^{1}(6323.3 \mathrm{~kg})$ was noted when bitter gorud was irrigated at 15 days interval. It was observed that bitter gourd fruit produced highest fruit yield $\left(\mathrm{kg} \mathrm{ha}^{-1}\right)$ when irrigated at 10 days interval + foliar application of urea at $3.0 \%$ conc. The LSD test demostrated signifcant increase $(\mathrm{P}<0.05)$ in fruit yield $(\mathrm{kg}$ $\mathrm{ha}^{-1}$ ) amongall irrigation levels.

Table 2.Effect of various combinations of irrigation frequencies and foliar application of urea in different conc. on Number of fruits vine ${ }^{-1}$, Weight of fruits vine ${ }^{-1}(\mathrm{~g})$ and Fruit yield $\left(\mathrm{kg} \mathrm{ha}^{-1}\right)$ of bitter gourd

\begin{tabular}{|c|c|c|c|}
\hline Treatments & $\begin{array}{c}\text { Number of fruits } \\
\text { vine }^{-1}\end{array}$ & $\begin{array}{c}\text { Weight of } \\
\text { fruits vine }^{-1}(\mathrm{~g})\end{array}$ & Fruit yield(kg ha-1 $)$ \\
\hline Control (irrigation at weekly interval) & $7.18 \mathrm{e}$ & $595.00 \mathrm{e}$ & $7876.7 \mathrm{~b}$ \\
\hline Irrigation at 10 days interval & $6.65 \mathrm{f}$ & $520.00 \mathrm{f}$ & $7305.0 \mathrm{bc}$ \\
\hline $\begin{array}{l}\text { Irrigation at } 10 \text { days interval + foliar } \\
\text { application of urea at } 1.5 \% \text { conc. }\end{array}$ & $8.55 \mathrm{~b}$ & $710.00 \mathrm{~b}$ & $9145.0 \mathrm{a}$ \\
\hline $\begin{array}{l}\text { Irrigation at } 10 \text { days interval + foliar } \\
\text { application of urea at } 3.0 \% \text { conc. }\end{array}$ & $8.95 \mathrm{a}$ & $739.00 \mathrm{a}$ & 9199.7 a \\
\hline Irrigation at 15 days interval & $5.15 \mathrm{~g}$ & $418.33 \mathrm{~g}$ & $6323.3 \mathrm{c}$ \\
\hline $\begin{array}{l}\text { Irrigation at } 15 \text { days interval + foliar } \\
\text { application of urea at } 1.5 \% \text { conc. }\end{array}$ & $7.85 \mathrm{~d}$ & $645.00 \mathrm{~d}$ & $8320.0 \mathrm{ab}$ \\
\hline $\begin{array}{l}\text { Irrigation at } 15 \text { days interval + foliar } \\
\text { application of urea at } 3.0 \% \text { conc. }\end{array}$ & $8.11 \mathrm{c}$ & $678.33 \mathrm{c}$ & $7940.0 \mathrm{~b}$ \\
\hline $\mathrm{SE} \pm$ & 0.1200 & 4.6876 & 534.22 \\
\hline LSD 0.05 & 0.2614 & 10.213 & 1164.0 \\
\hline $\mathrm{CV}(\%)$ & 1.96 & 0.93 & 8.16 \\
\hline
\end{tabular}

\section{Discussion}

The current study was performed to evaluate the growth and yield response of bitter gourd to foliar applied urea under different irrigation levels. The irrigation frequencies at 10 days interval + foliar application of urea at $3.0 \%$ conc. resulted $144.95 \mathrm{~cm}$ vine length, $19.96 \mathrm{~cm}$ fruit length, $17.45 \mathrm{~cm}$ diameter of fruit, $79.95 \mathrm{~g}$ average fruit weight, 8.95 number of fruits vine ${ }^{-1}, 739.00 \mathrm{~kg}$ weight of fruits vine ${ }^{-1}$ and $9199.7 \mathrm{~kg} \mathrm{ha}^{-1}$ fruit yield. The irrigation frequencies at 10 days interval + foliar application of urea at $1.5 \%$ conc. resulted $143.50 \mathrm{~cm}$ vine length, $17.98 \mathrm{~cm}$ fruit length, $16.63 \mathrm{~cm}$ diameter of fruit, 77.47 $\mathrm{g}$ average fruit weight, 8.55 number of fruits vine $^{-1}, 710.00 \mathrm{~g}$ weight of fruits vine ${ }^{-1}$ and $9145.0 \mathrm{~kg} \mathrm{ha}^{-1}$ fruit yield. The bitter gourd fruit received irrigation frequencies at 15 days interval + foliar application of urea at $3.0 \%$ conc. resulted $142.00 \mathrm{~cm}$ vine length, 17.10 $\mathrm{cm}$ fruit length, $16.27 \mathrm{~cm}$ diameter of fruit, $75.50 \mathrm{~g}$ average fruit weight, 8.11 number of fruits vine ${ }^{-1}, 678.33 \mathrm{~g}$ weight of fruits vine ${ }^{1}$ and $7940.0 \mathrm{~kg} \mathrm{ha}^{-1}$ fruit yield. Irrigation frequencies at 15 days interval + foliar application of urea at $1.5 \%$ conc. resulted $139.50 \mathrm{~cm}$ vine length, $17.10 \mathrm{~cm}$ fruit length, 
$15.55 \mathrm{~cm}$ diameter of fruit, $71.83 \mathrm{~g}$ average fruit weight, 7.85 number of fruits $v^{-1} e^{-1}$, $645.00 \mathrm{~g}$ weight of fruits vine ${ }^{-1}$ and $8320.0 \mathrm{~kg}$ $\mathrm{ha}^{-1}$ fruit yield. The bitter gourd irrigated at control (irrigation at weekly interval) resulted $134.50 \mathrm{~cm}$ vine length, $16.04 \mathrm{~cm}$ fruit length, $15.27 \mathrm{~cm}$ diameter of fruit, $67.86 \mathrm{~g}$ average fruit weight, 7.18 number of fruits vine $^{-1}$, $595.00 \mathrm{~g}$ weight of fruits vine ${ }^{-1}$ and $7876.7 \mathrm{~kg}$ $\mathrm{ha}^{-1}$ fruit yield. The irrigation frequencies at 10 days interval resulted $124.50 \mathrm{~cm}$ vine length, $15.61 \mathrm{~cm}$ fruit length, $15.70 \mathrm{~cm}$ diameter of fruit, $62.00 \mathrm{~g}$ average fruit weight, 6.65 number of fruits vine ${ }^{-1}, 520.00 \mathrm{~kg}$ weight of fruits vine ${ }^{-1}$ and $7305.0 \mathrm{~kg} \mathrm{ha}^{-1}$ fruit yield. The bitter gourd irrigated at 15 days interval resulted $120.50 \mathrm{~cm}$ vine length, $11.96 \mathrm{~cm}$ fruit length, $12.43 \mathrm{~cm}$ diameter of fruit, 52.00 g average fruit weight, 5.15 number of fruits vine $^{-1}, 418.33 \mathrm{~g}$ weight of fruits vine $^{-1}$ and $6323.3 \mathrm{~kg} \mathrm{ha}^{-1}$ fruit yield. The values for all the growth and productivity of bitter gourd were markedly increased when crop irrigated at 10 days interval + foliar application of urea at $3.0 \%$ conc. These agree results with the finds of Asoegwu [20] who observed a decrease in the number of leaves with increase in irrigation interval. Similar findings were reported Channabasavanna and Setty [21] for sweet pepper. In their research findings showed an increase in growth and yield parameters with increasing organic and inorganic fertilizers up to a point, after which the parameters start decreasing. For example Olaniyi and Odedere [22] observed that although the application of 6 tha $^{-1}$ compost gave the highest growth and yield parameters of fluted pumpkin, there was no significant difference between the values obtained at 4.5 and 6 tha $^{-1}$. However Polat et al. [23] found that there were statistically significant differences among different levels of spent mushroom compost applied, in terms of total yield of lettuce, as 2 and 4 tha $^{-1}$ gave the best result. In the case of cucumber grown in green houses with drip irrigation also observed that the highest total fruit yield under similar dose rate.

\section{Conclusions}

It is concluded that the values for all the growth and yield traits of bitter gourd were markedly increased when irrigted at 10 days interval + foliar application of urea at $3.0 \%$ conc.It is suggested that for better growth and productivity, Bitter gourd may be irrigated at 10 days interval + foliar application of urea at $3.0 \%$ concentration.

\section{Authors' contributions}

Conceived and designed the experiments: FM Bangulzaiand \& A Samad, Performed the experiments: A Samad \& FM Bangulzai, Analyzed the data: N Ahmed, Contributed reagents/materials/analysis tools: $\mathrm{Z}$ Bibi, $\mathrm{L}$ Bakhsh, A Raziq \&SM Ishaq, Wrote the paper: FM Bangulzai \& A Samad.

\section{References}

1. Rashid M (2004). Effect of photoperiod and growth substances on sex expression in bitter gourd (Trichosanthes anguina L.) $S$ Indi Hort 15: 1-21.

2. Miniraj N, Prasanna KP \& Peter KV (1993). Bitter gourd Mornordicu app. pp 239-246. In: C. Kalloo \& 8.0. Bergh (ads.), Gen impro of vege plants. Pergamon Press, Oxf UK.

3. Krawinkel MB \& Keding GB (2006). Bitter gourd (Momordica charantia): A dietary approach to hyperglycemia. Nutr Rev 64(7 Pt 1): 331-337.

4. Sabira B, Mansour A, Bina SS, Abdullah K, Zafar SS, and Mohammed A. (1997). Triterpenes, a sterol, and a monocyclic alcohol from Momordica charantia. Phytochem 4(7): 1313-1320.

5. Chen Q, Chan LL \& Li ET (2003). Bitter melon (Momordica charantia) reduces adiposity, lowers serum insulin and normalizes glucose tolerance in rats fed a high fat diet. The J of Nutria 133(4): 108893.

6. Zapata, M \& Segura P (1995). Riego deficitario controlado: Fundamentos y aplicaciones. Ediciones Mundi Prensa, Madrid, España, pp 188. 
7. Webber HA, Madramootoo CA, Bourgault M, Horst MG, Stulina G \& Smith DI (2006). Water use efficiency of common bean and green gram grown using alternate furrow and deficit irrigation. Agric W Manage 86: 259- 268.

8. Zegbe JA, Hossein $\mathrm{M} \&$ Clothier BE (2006). Responses of 'Petopride' processing tomato to partial rootzone drying at different phenological stages. Irrig Sci 24: 203-210.

9. Richards R, Rebetzke GJ, Condon AG \& Herwaarden AF (2002). Breeding opportunities for increasing and crop the efficiency of water use yield in temperate cereals. Crop Sci 42: 111-121.

10. Wayne PH (2002). Implications of atmospheric and climate change for crop yield and water use efficiency. Crop Sci42: 131-139.

11. Rolbiecki R \& Rolbiecki S (2009). Effects of micro-irrigation systems on lettuce and radish production. Proc. III Balkan Symposium on Vegetables and Potatoes, Abst. ISHS Acta Hort pp 729.

12. Oosterhuis DM \& Bondada BR (2001). Yield response of cotton to foliar nitrogen as influenced by sink strength, petiole, and soil nitrogen. J Plant Nutr 24: 413-422.

13. Arif $M$, Chohan MA, Ali $S$ \& Khan $S$ (2006). Response of wheat to foliar application of nutrients. J Agri Bio Sci1: 30-34.

14. Uwah DF \& Solomon $M G$ (1998). Effects of nitrogen and phosphorus on yield and yield component of watermelon (Citrullusl anatusthunb Mansf.). J of App Chem and Agric Res 5: 48-53.

15. Uwah DF, Ahmed MK, Amans EB \& Chiezey UF (2006). Nitrogen and phosphorous effects on the field performance of watermelon (Citrulluslanatus (Thunb.) Mansf. $J$ of Agric Biotech and Eco 3(1): 10-22.

16. Elmstrom GW, Fiskell JGA \& Martin FG (2003). Effect of NPK fertilizers on watermelon yield and quality. $J$ of the Flor Sta Hort Soci 3(3/4): 21-29.

17. Salman SR, Abou-hussein SD, AbdelMawgoud AMR \& El-Nemr MA (2005). Fruit Yield and Quality of Watermelon as Affected by Hybrids and Humic Acid Application. J of App Sci Res 1(1): 51-58.

18. Santos GRD (2009). Effect of nitrogen doses on disease severity and watermelon yield. Hortic Bras 27(3): 330-334.

19. Steel RGD, Torri JH \& Dickey DA (1997). Principles and procedures of statistics. A biometric approach $3^{\text {rd }}$ ed Mc Grow Hill Book Co. Inc New York USA.

20. Asoegwu SN (2012). Effects of irrigation on the leaf and pod production of fluted pumpkin Telfairiaoccidentalis Hook. F.) in Southern Nigeria. Sci. Hort 34: 161-168.

21. Channabasavanna AS \& Setty RA (2000). Effect of different irrigation Intervals on sweet pepper. S Indi-Hort 39(5): 296-299.

22. Olaniyi JO \& Odedere MP (2009). The effects of mineral $\mathrm{N}$ and compost fertilizers on the growth, yield and nutritional values of fluted pumpkin (Telfairiaoccidentalis) in south western Nigeria. J Anim Plant Sci 5(1): 443-449.

23. Polat E, Onus AN \& Demir H (2009). The effects of spent mushroom compost on yield and quality in lettuce growing. $J$ Fac Agric Akdeniz Uni 17(2): 149-154. 